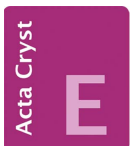

CRYSTALLOGRAPHIC COMMUNICATIONS

ISSN 2056-9890

Received 29 April 2016

Accepted 6 June 2016

Edited by M. Weil, Vienna University of Technology, Austria

Keywords: crystal structure; redetermination; ruizite; finite silicate chain.

CCDC reference: 1483820

Supporting information: this article has supporting information at journals.iucr.org/e

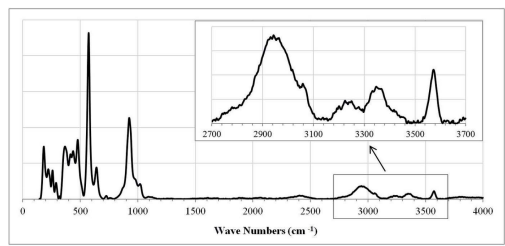

OPEN $\odot$ ACCESS

\section{Redetermination of ruizite, $\mathrm{Ca}_{2} \mathrm{Mn}_{2}^{3+}\left[\mathrm{Si}_{4} \mathrm{O}_{11}(\mathrm{OH})_{2}\right](\mathrm{OH})_{2} \cdot 2 \mathrm{H}_{2} \mathrm{O}$}

\author{
Kim V. Fendrich, ${ }^{*}$ Robert T. Downs and Marcus J. Origlieri
}

University of Arizona, 1040 E. 4th Street, Tucson, AZ 85721, USA. *Correspondence e-mail: kfendrich@email.arizona.edu

The crystal structure of ruizite, ideally $\mathrm{Ca}_{2} \mathrm{Mn}^{3+}{ }_{2}\left[\mathrm{Si}_{4} \mathrm{O}_{11}(\mathrm{OH})_{2}\right](\mathrm{OH})_{2} \cdot 2 \mathrm{H}_{2} \mathrm{O}$ [dicalcium dimanganese(III) tetrasilicate tetrahydroxide dihydrate] was first determined in space group $A 2$ with an isotropic displacement parameter model $(R=5.6 \%)$ [Hawthorne (1984). Tschermaks Mineral. Petrogr. Mitt. 33, 135-146]. A subsequent refinement in space group $C 2 / m$ with anisotropic displacement parameters for non-H atoms converged with $R=8.4 \%$ [Moore et al. (1985). Am. Mineral. 70, 171-181]. The current study reports a redetermination of the ruizite structure by means of single-crystal X-ray diffraction data of a natural sample from the Wessels mine, Kalahari Manganese Field, Northern Cape Province, South Africa. Our data $\left(R_{1}=3.0 \%\right)$ confirm that the space group of ruizite is that of the first study rather than $C 2 / m$. This work improves upon the structure reported by Hawthorne (1984) in that all non-H atoms were refined with anisotropic displacement parameters and all hydrogen atoms were located. The crystal structure consists of [010] chains of edge-sharing $\mathrm{MnO}_{6}$ octahedra flanked by finite $\left[\mathrm{Si}_{4} \mathrm{O}_{11}(\mathrm{OH})_{2}\right]$ chains. The $\mathrm{Ca}^{2+}$ cations are situated in the cavities of this arrangement and exhibit a coordination number of seven.

\section{Mineralogical and crystal-chemical context}

Ruizite from the Christmas mine, Gila County, Arizona, USA, was originally described by Williams \& Duggan (1977) with monoclinic symmetry in the space group $P 2_{1} / c$ and unit-cell parameters $a=11.95, b=6.17, c=9.03 \AA$, $\beta=91.38^{\circ}$ based on rotation and Weissenberg photographs. Ideal chemistry was

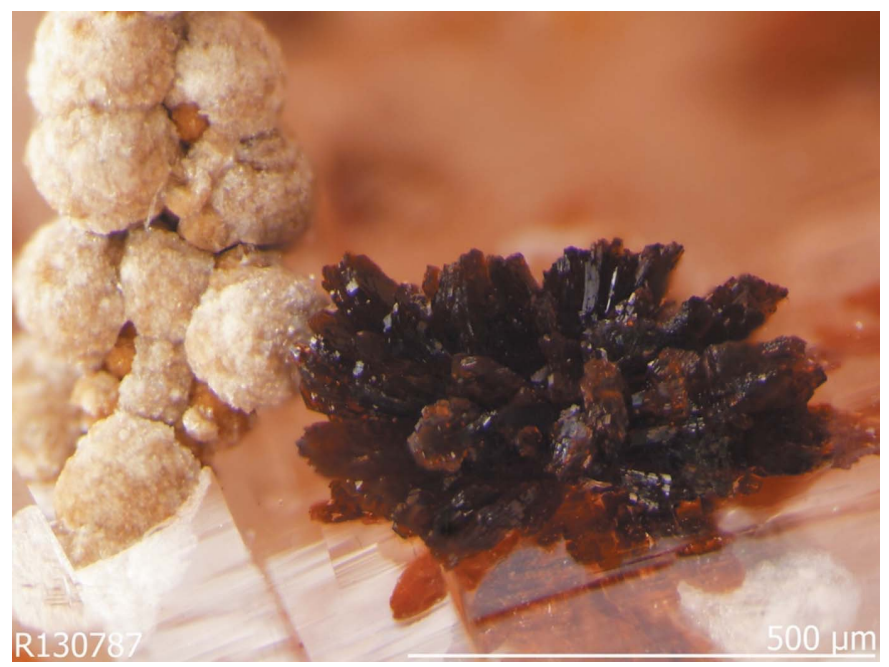

Figure 1

Photograph of the ruizite specimen analyzed in this study. 
Table 1

Chemical composition and unit-cell parameters $\left(\AA, \AA^{3}\right)$ of different ruizite samples.

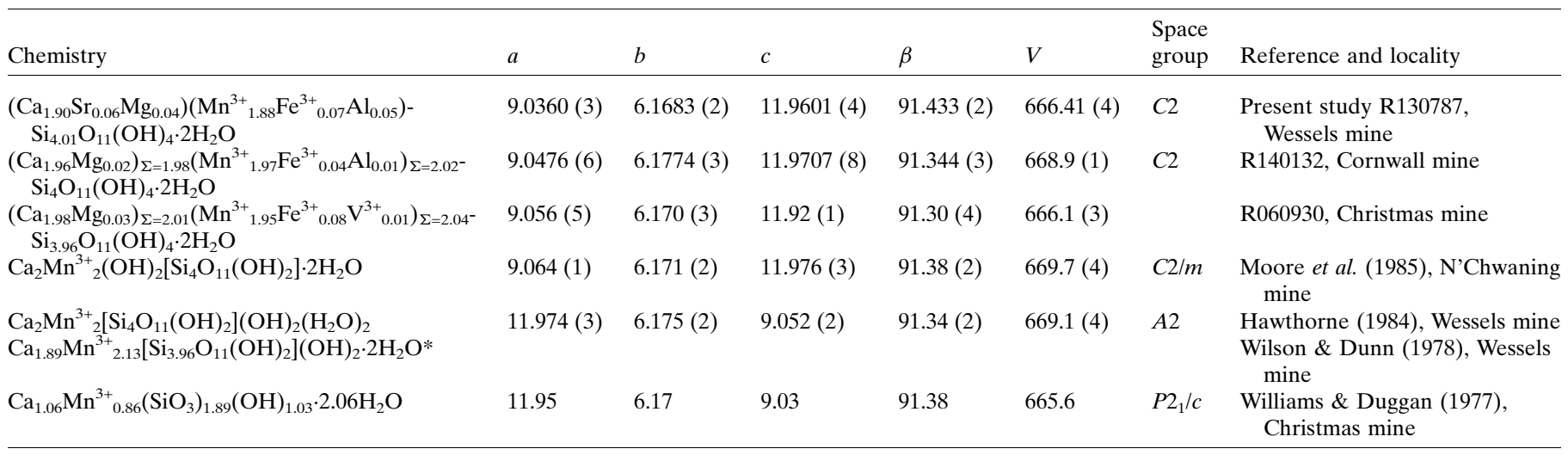

* Recalculated based on $17 \mathrm{O}$ atoms, as in the currently accepted formula.

proposed as $\mathrm{CaMn}\left(\mathrm{SiO}_{3}\right)_{2}(\mathrm{OH}) \cdot 2 \mathrm{H}_{2} \mathrm{O}$. Wilson \& Dunn (1978) reported a second occurrence of ruizite from the Wessels mine, Kalahari Manganese Field, Northern Cape Province, South Africa, with the same chemical formula as that given by Williams \& Duggan (1977).

To date, ruizite has been found at five different localities (Table 1): Christmas mine, Gila County, Arizona, USA (Williams \& Duggan, 1977); Wessels mine (Wilson \& Dunn,
1978) and N'Chwaning mines (Moore et al., 1985) in the Northern Cape Province, South Africa; Cornwall mine, Lebanon County, Pennsylvania, USA (Kearns \& Kearns, 2008); and the Cerchiara mine, Liguria, Italy (Balestra et al., 2009). It is a product of retrograde metamorphism and oxidation during cooling of calc-silicate rocks formed via contact metamorphism of limestones (Williams \& Duggan, 1977). The secondary mineralization of ruizite at the type

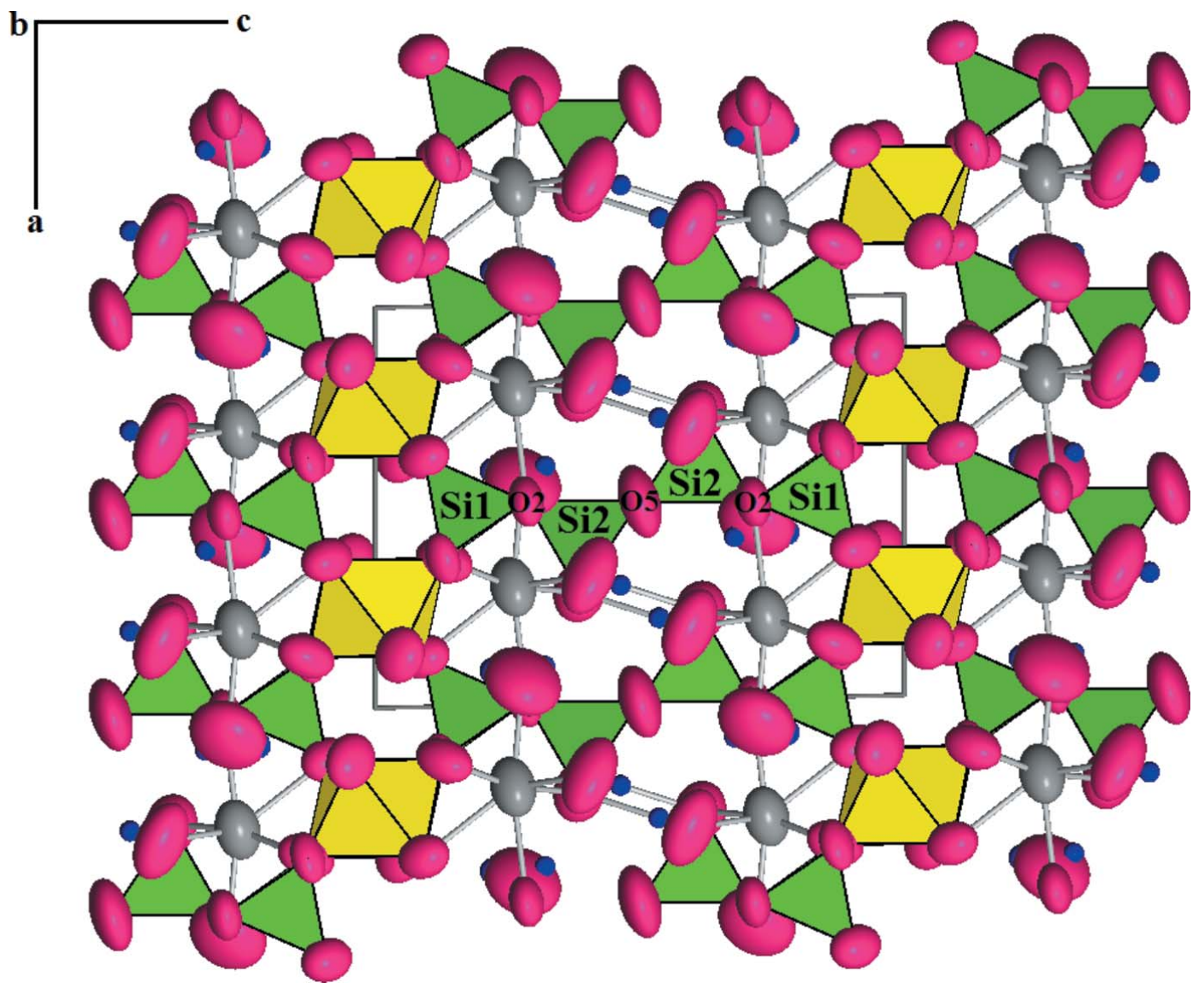

Figure 2

The crystal structure of ruizite as reported in this paper, viewed down $b$. Pink and gray ellipsoids represent $\mathrm{O}$ and $\mathrm{Ca}$ atoms, respectively. $\mathrm{SiO} \mathrm{O}_{4}$ tetrahedra are shown in green and $\mathrm{MnO}_{6}$ octahedra in yellow. Hydrogen atoms are represented by small dark-blue spheres. 
Table 2

Hydrogen-bond geometry $\left(\AA,^{\circ}\right)$.

\begin{tabular}{|c|c|c|c|c|}
\hline$D-\mathrm{H} \cdots A$ & $D-\mathrm{H}$ & $\mathrm{H} \cdots A$ & $D \cdots A$ & $D-\mathrm{H} \cdots A$ \\
\hline $\mathrm{O} 7-\mathrm{H} 1 \cdots \mathrm{O} 6^{\mathrm{i}}$ & $0.73(6)$ & $1.94(6)$ & $2.662(4)$ & $168(8)$ \\
\hline $\mathrm{O} 8-\mathrm{H} 2 \cdots \mathrm{O} 9$ & $0.64(6)$ & $2.28(6)$ & $2.842(4)$ & $149(9)$ \\
\hline $\mathrm{O} 9-\mathrm{H} 3 \cdots \mathrm{O} 6$ & $0.74(8)$ & $2.06(8)$ & $2.737(6)$ & $153(7)$ \\
\hline $\mathrm{O} 9-\mathrm{H} 4 \cdots \mathrm{O} 8$ & $0.72(6)$ & $2.14(6)$ & $2.842(4)$ & $167(9)$ \\
\hline
\end{tabular}

Symmetry code: (i) $-x+\frac{3}{2}, y-\frac{1}{2},-z+1$.

locality may have occurred during the Cretaceous or sometime thereafter (Peterson \& Swanson, 1956).

The structure of ruizite was first determined by Hawthorne (1984) on the basis of space group $A 2$, in the same setting as reported by Williams \& Duggan (1977), using a crystal from the Wessels mine. The structure refinement yielded an $R$ factor of $5.6 \%$ for an isotropic displacement model in which positions of three of the four hydrogen atoms were located. Refinement of anisotropic displacement parameters was not successful. The ideal chemical formula was revised to $\mathrm{Ca}_{2} \mathrm{Mn}_{2}{ }_{2}^{\mathrm{III}}\left[\mathrm{Si}_{4} \mathrm{O}_{11}(\mathrm{OH})_{2}\right](\mathrm{OH})_{2}\left(\mathrm{H}_{2} \mathrm{O}\right)_{2}$. Moore et al. (1985) reexamined the ruizite structure using a sample from the N'Chwaning mine and reported space group $C 2 / m$, a cell setting different from that adopted by Hawthorne (1984). The structure was refined with anisotropic displacement parameters for non-H atoms, yielding an $R$ factor of $8.4 \%$; no hydrogen atoms were located. However, most of the resulting displacement ellipsoids were unreasonable or non-positive definite. Moore et al. (1985) presented a disclaimer that 'the anisotropic thermal parameters for these crystals are more likely manifestations of intergrowths and domain disorder, rather than descriptions of true thermal motions'.

The current study reports a redetermination of the ruizite structure by means of single-crystal X-ray diffraction data of a natural sample from the Wessels mine, Kalahari Manganese Field, Northern Cape Province, South Africa (Fig. 1).

\section{Structural commentary}

The structure of ruizite is characterized by chains of edgesharing $\mathrm{MnO}_{6}$ octahedra extending along [010], which are linked by corner-sharing with $\mathrm{SiO}_{4}$ tetrahedra that form short $\left[\mathrm{Si}_{4} \mathrm{O}_{11}(\mathrm{OH})_{2}\right]$ chains, giving rise to a three-dimensional network (Fig. 2). The finite $\left[\mathrm{Si}_{4} \mathrm{O}_{11}(\mathrm{OH})_{2}\right]$ chain in ruizite is the only reported silicate chain of this type. The relatively large $\mathrm{Ca}^{2+}$ cations occupy the interstitial cavities and exhibit a coordination number of seven $[\mathrm{Ca}-\mathrm{O}$ bond-length range

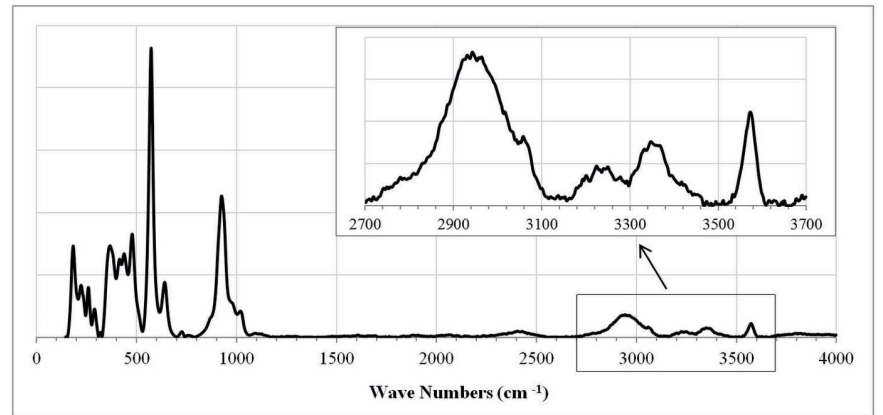

Figure 3

Broad-scan Raman spectrum of an unoriented ruizite specimen (R130787).

2.348 (4)-2.606 (3) §]. The $\mathrm{Mn}^{3+}$ cations are bonded to four $\mathrm{O}$ atoms (O3, O4, and two $\mathrm{O} 1$ atoms) and two $\mathrm{OH}$ groups (O8$\mathrm{H} 2$ ), resulting in a distorted $\mathrm{MnO}_{6}$ octahedron, with an octahedral angle variance of 27.35 and a quadratic elongation index of 1.015 (Robinson et al., 1971). The $\mathrm{Si1O}_{4}$ tetrahedron is more distorted than $\mathrm{Si}_{2} \mathrm{O}_{4}$, as indicated by angular variances (26.37 vs 10.18) and quadratic elongation indices (1.007 vs 1.003). Both average $\mathrm{Si} 1-\mathrm{O}_{\mathrm{nbr}}$ and $\mathrm{Si} 2-\mathrm{O}_{\mathrm{nbr}}$ bond lengths (nbr = non-bridging) are $1.618 \AA$. The $\mathrm{Si} 2-\mathrm{O} 7$ separation $(1.642 \AA)$ is longer than the average $\mathrm{Si} 2-\mathrm{O}_{\mathrm{nbr}}$ length because $\mathrm{O} 7$ is the hydroxyl group that is also bonded to a $\mathrm{Ca}^{2+}$ cation. The $\mathrm{O} 5$ atom is located on a twofold rotation axis and bridges the two $\mathrm{Si} 2$ atoms with a $\mathrm{Si}-\mathrm{O}$ bond length of 1.6031 (13) $\AA$, which is most likely a result of the considerably large $\mathrm{Si} 2-$ O5-Si2 angle $\left[162.9(3)^{\circ}\right]$ when compared to the Si1-O2$\mathrm{Si} 2$ angle [128.27 (18) $)^{\circ}$ (Gibbs et al., 1994).

The hydrogen-bonding scheme in ruizite is presented in Table 2. The $\mathrm{O} 9$ atom is bonded to atoms $\mathrm{H} 3$ and $\mathrm{H} 4$, forming a water molecule whereas the $\mathrm{O} 7$ and $\mathrm{O} 8$ atoms are bonded to $\mathrm{H} 1$ and $\mathrm{H} 2$, respectively, to form two distinct $\mathrm{OH}$ groups. The bond-valence calculations (Brown, 2002) confirm the model (Table 3). The O6 atom is markedly underbonded because it is an acceptor for both $\mathrm{H} 1$ and $\mathrm{H} 3$, and consequently it is associated with the shortest $\mathrm{Si}-\mathrm{O}$ and $\mathrm{Ca}-\mathrm{O}$ bond lengths. It is interesting to note that all hydrogen bonds in ruizite are shorter than $2.85 \AA$ (Table 2). Nevertheless, the Raman spectrum shows a relatively sharp band at $3570 \mathrm{~cm}^{-1}$ (see below). According to Libowitzky (1999), this band would correspond to a hydrogen bond length $(\mathrm{O} \cdots \mathrm{O})$ of $3.1-3.3 \AA$. Perhaps $\mathrm{O} 7-\mathrm{H} 1$ forms a bifurcated hydrogen bond, where $\mathrm{H} 1$ is bonded to both $\mathrm{O} 6$ and $\mathrm{O} 5$. The O7..O5 distance is $3.354 \AA$, which could explain the band at $3570 \mathrm{~cm}^{-1}$ (Libowitzky, 1999).

Table 3

Bond-valence sums.

\begin{tabular}{|c|c|c|c|c|c|c|c|c|c|c|}
\hline & $\mathrm{O} 1$ & $\mathrm{O} 2$ & O3 & O4 & O5 & O6 & $\mathrm{O} 7$ & $\mathrm{O} 8$ & O9 & $\Sigma_{M}$ \\
\hline $\mathrm{Mn}$ & $0.317_{\times 2 \downarrow} \rightarrow$ & & 0.674 & 0.668 & & & & $0.599_{\times 2} \rightarrow$ & & 3.173 \\
\hline Si1 & 1.044 & 0.898 & 0.971 & 1.036 & & & & & & 3.949 \\
\hline$\Sigma_{0}$ & 1.881 & 2.033 & 1.937 & 1.988 & 2.116 & 1.444 & 1.225 & 1.198 & 0.322 & \\
\hline
\end{tabular}


Table 4

Experimental details.

\begin{tabular}{|c|c|}
\hline \multicolumn{2}{|l|}{ Crystal data } \\
\hline Chemical formula & $\begin{array}{l}\mathrm{Ca}_{2} \mathrm{Mn}^{3+}{ }_{2}\left[\mathrm{Si}_{4} \mathrm{O}_{11}(\mathrm{OH})_{2}\right](\mathrm{OH})_{2} \cdot- \\
\quad 2 \mathrm{H}_{2} \mathrm{O}\end{array}$ \\
\hline$M_{\mathrm{r}}$ & 582.46 \\
\hline Crystal system, space group & Monoclinic, $C 2$ \\
\hline Temperature $(\mathrm{K})$ & 293 \\
\hline$a, b, c(\AA)$ & $9.0360(3), 6.1683(2), 11.9601$ (4) \\
\hline$\beta\left({ }^{\circ}\right)$ & $91.433(2)$ \\
\hline$V\left(\AA^{6}\right)$ & $666.41(4)$ \\
\hline$Z$ & 2 \\
\hline Radiation type & Mo $K \alpha$ \\
\hline$\mu\left(\mathrm{mm}^{-1}\right)$ & 3.13 \\
\hline Crystal size $(\mathrm{mm})$ & $0.06 \times 0.04 \times 0.04$ \\
\hline \multicolumn{2}{|l|}{ Data collection } \\
\hline Diffractometer & $\begin{array}{l}\text { Bruker APEXII CCD area- } \\
\text { detector }\end{array}$ \\
\hline Absorption correction & $\begin{array}{l}\text { Multi-scan (SADABS; Bruker, } \\
\text { 2004) }\end{array}$ \\
\hline $\begin{array}{l}\text { No. of measured, independent and } \\
\text { observed }[I>2 \sigma(I)] \text { reflections }\end{array}$ & $4997,2038,1732$ \\
\hline$R_{\text {int }}$ & 0.029 \\
\hline$(\sin \theta / \lambda)_{\max }\left(\AA^{-1}\right)$ & 0.758 \\
\hline \multicolumn{2}{|l|}{ Refinement } \\
\hline$R\left[F^{2}>2 \sigma\left(F^{2}\right)\right], w R\left(F^{2}\right), S$ & $0.030,0.065,1.06$ \\
\hline No. of reflections & 2038 \\
\hline No. of parameters & 127 \\
\hline No. of restraints & 1 \\
\hline H-atom treatment & Only H-atom coordinates refined \\
\hline$\Delta \rho_{\max }, \Delta \rho_{\min }\left(\mathrm{e} \AA^{-3}\right)$ & $0.60,-0.53$ \\
\hline Absolute structure & Refined as an inversion twin. \\
\hline Absolute structure parameter & $0.18(5)$ \\
\hline
\end{tabular}

Computer programs: APEX2 and SAINT (Bruker, 2004), SHELXT (Sheldrick, 2015a), SHELXL2014/7 (Sheldrick, 2015b), XtalDraw (Downs \& Hall-Wallace, 2003) and publCIF (Westrip, 2010).

Fig. 3 is a plot of the Raman spectrum of ruizite. A tentative assignment of the major Raman bands is as follows: The bands between 2800 and $3600 \mathrm{~cm}^{-1}$ are due to the $\mathrm{O}-\mathrm{H}$ stretching vibrations. The short $\mathrm{H} 2 \cdots \mathrm{H} 4$ distance $(1.58 \AA)$ may be a result of disordering of one of the hydrogen atoms, which may also explain the considerably broad $\mathrm{O}-\mathrm{H}$ stretching band in the Raman spectrum around $2940 \mathrm{~cm}^{-1}$. The bands in the $1050-800 \mathrm{~cm}^{-1}$ region can be attributed to the $\mathrm{Si}-\mathrm{O}$ stretching vibrations within the $\mathrm{SiO}_{4}$ groups and those in the range of $670-520 \mathrm{~cm}^{-1}$ to the $\mathrm{O}-\mathrm{Si}-\mathrm{O}$ bending vibrations within the $\mathrm{SiO}_{4}$ tetrahedra. The bands below $500 \mathrm{~cm}^{-1}$ are mainly associated with the rotational and translational modes of $\mathrm{SiO}_{4}$ tetrahedra, and the $\mathrm{MnO}_{6}$ and $\mathrm{CaO}_{7}$ polyhedral interactions.

\section{Synthesis and crystallization}

The ruizite crystal used in this study is from the Wessels mine, Kalahari Manganese Field, Northern Cape Province, South Africa (Fig. 1) and is in the collection of the RRUFF project (http://rruff.info/R130787). Its chemical composition was measured using a CAMECA SX 100 electron microprobe at the conditions of $15 \mathrm{keV}, 20 \mathrm{nA}$ and a beam size $<1 \mu \mathrm{m}$. The composition, calculated on the basis of 17 oxygen atoms and an estimation of $\mathrm{H}_{2} \mathrm{O}$ by difference is $\left(\mathrm{Ca}_{1.90} \mathrm{Sr}_{0.06} \mathrm{Mg}_{0.04}\right)$ $\left(\mathrm{Mn}^{3+}{ }_{1.88} \mathrm{Fe}^{3+}{ }_{0.07} \mathrm{Al}_{0.05}\right) \mathrm{Si}_{4.01} \mathrm{O}_{11}(\mathrm{OH})_{4} \cdot 2 \mathrm{H}_{2} \mathrm{O}$.

The Raman spectrum of ruizite was collected from a randomly oriented crystal at $100 \%$ power of $150 \mathrm{~mW}$ on a Thermo Almega microRaman system, using a solid-state laser with a wavelength of $532 \mathrm{~nm}$, and a thermoelectrically cooled CCD detector. The laser was partially polarized with $4 \mathrm{~cm}^{-1}$ resolution and a spot size of $1 \mu \mathrm{m}$.

\section{Refinement}

Crystal data, data collection and structure refinement details are summarized in Table 4 . The crystal structure was solved and refined based on space group $C 2$ because it yielded better refinement statistics than in $C 2 / m$ in terms of bond lengths and angles, atomic displacement parameters, and $R$ factors. The crystal under investigation was twinned by inversion (Table 4). Electron microprobe analysis revealed that the ruizite sample studied contains small amounts of $\mathrm{Sr}, \mathrm{Mg}, \mathrm{Fe}$, and $\mathrm{Al}$. However, the overall effects of minor and trace amounts of these elements are negligible; therefore, the ideal chemical formula $\mathrm{Ca}_{2} \mathrm{Mn}^{3+}{ }_{2}\left[\mathrm{Si}_{4} \mathrm{O}_{11}(\mathrm{OH})_{2}\right](\mathrm{OH})_{2} \cdot 2 \mathrm{H}_{2} \mathrm{O}$ was assumed during refinement. The $\mathrm{H}$ atoms were located from difference Fourier syntheses and confirmed by bond valence sum calculations. Their positions were refined with a fixed isotropic displacement parameter $\left(U_{\text {iso }}=0.04\right)$. The maximum residual electron density in the difference Fourier map, 0.60 e $\AA^{-3}$, was located at $0.85 \AA$ from 08 and the minimum density at $0.17 \AA$ from $\mathrm{H} 4$.

\section{Acknowledgements}

The authors gratefully acknowledge support of this study from the Arizona Science Foundation and NASA NNX11AP82A, Mars Science Laboratory Investigations. Any opinions, findings, and conclusions or recommendations expressed in this material are those of the author $(s)$ and do not necessarily reflect the views of the National Aeronautics and Space Administration.

\section{References}

Balestra, C., Kolitsch, U., Blass, G., Callegari, A. M., Boiocchi, M., Armellino, G., Ciriotti, M. E., Ambrino, P. \& Bracco, R. (2009). Micro, 1-2009, 78-99.

Brown, I. D. (2002). The Chemical Bond in Inorganic Chemistry: The Bond Valence Model. Oxford University Press.

Bruker (2004). SADABS, APEX2 and SAINT. Bruker AXS Inc., Madison, Wisconsin, USA.

Downs, R. T. \& Hall-Wallace, M. (2003). Am. Mineral. 88, 247-250.

Gibbs, G. V., Downs, J. W. \& Boisen, M. B. (1994). Rev. Min. Geochem. 29, 332-368.

Hawthorne, F. C. (1984). Tschermaks Mineral. Petrogr. Mitt. 33, 135146.

Kearns, L. E. \& Kearns, C. A. (2008). Mineral. News, 24, 8-9.

Libowitzky, E. (1999). Monatsh. Chem. 130, 1047-1059.

Moore, P. B., Shen, J. \& Araki, T. (1985). Am. Mineral. 70, 171-181.

Peterson, N. P. \& Swanson, R. W. (1956). U. S. Geol. Surv. Bull. 1027H, 351-373.

Robinson, K., Gibbs, G. V. \& Ribbe, P. H. (1971). Science, 172, 567570. 
Sheldrick, G. M. (2015a). Acta Cryst. A71, 3-8. Sheldrick, G. M. (2015b). Acta Cryst. C71, 3-8.

Westrip, S. P. (2010). J. Appl. Cryst. 43, 920-925.
Williams, S. A. \& Duggan, M. (1977). Mineral. Mag. 41, 429-432.

Wilson, W. E. \& Dunn, P. J. (1978). Miner. Rec. 9, 137-153. 


\section{supporting information}

Acta Cryst. (2016). E72, 959-963 [https://doi.org/10.1107/S2056989016009129]

\section{Redetermination of ruizite, $\mathrm{Ca}_{2} \mathrm{Mn}^{3+}{ }_{2}\left[\mathrm{Si}_{4} \mathrm{O}_{11}(\mathrm{OH})_{2}\right](\mathrm{OH})_{2} \cdot 2 \mathrm{H}_{2} \mathrm{O}$}

\section{Kim V. Fendrich, Robert T. Downs and Marcus J. Origlieri}

Computing details

Data collection: APEX2 (Bruker, 2004); cell refinement: SAINT (Bruker, 2004); data reduction: SAINT (Bruker, 2004); program(s) used to solve structure: SHELXT (Sheldrick, 2015a); program(s) used to refine structure: SHELXL2014/7 (Sheldrick, 2015b); molecular graphics: XtalDraw (Downs \& Hall-Wallace, 2003); software used to prepare material for publication: publCIF (Westrip, 2010).

Dicalcium dimanganese(III) tetrasilicate tetrahydroxide dihydrate

Crystal data

$\mathrm{Ca}_{2} \mathrm{H}_{8} \mathrm{Mn}_{2} \mathrm{O}_{17} \mathrm{Si}_{4}$

$M_{r}=582.46$

Monoclinic, $C 2$

$a=9.0360(3) \AA$

$b=6.1683(2) \AA$

$c=11.9601(4) \AA$

$\beta=91.433(2)^{\circ}$

$V=666.41(4) \AA^{3}$

$Z=2$

Data collection

Bruker APEXII CCD area-detector diffractometer

Radiation source: fine-focus sealed tube $\varphi$ and $\omega$ scan Absorption correction: multi-scan

(SADABS; Bruker, 2004)

4997 measured reflections

Refinement

Refinement on $F^{2}$

Least-squares matrix: full

$R\left[F^{2}>2 \sigma\left(F^{2}\right)\right]=0.030$

$w R\left(F^{2}\right)=0.065$

$S=1.06$

2038 reflections

127 parameters

1 restraint

Hydrogen site location: difference Fourier map
$F(000)=580$

$D_{\mathrm{x}}=2.903 \mathrm{Mg} \mathrm{m}^{-3}$

Mo $K \alpha$ radiation, $\lambda=0.71073 \AA$

Cell parameters from 1284 reflections

$\theta=8.0-63.1^{\circ}$

$\mu=3.13 \mathrm{~mm}^{-1}$

$T=293 \mathrm{~K}$

Prismatic, brown

$0.06 \times 0.04 \times 0.04 \mathrm{~mm}$

2038 independent reflections 1732 reflections with $I>2 \sigma(I)$

$R_{\text {int }}=0.029$

$\theta_{\text {max }}=32.6^{\circ}, \theta_{\min }=4.0^{\circ}$

$h=-13 \rightarrow 13$

$k=-9 \rightarrow 8$

$l=-18 \rightarrow 18$

Only $\mathrm{H}$-atom coordinates refined

$w=1 /\left[\sigma^{2}\left(F_{\mathrm{o}}^{2}\right)+(0.0243 P)^{2}+0.6718 P\right]$ where $P=\left(F_{\mathrm{o}}^{2}+2 F_{\mathrm{c}}^{2}\right) / 3$

$(\Delta / \sigma)_{\max }<0.001$

$\Delta \rho_{\max }=0.60$ e $\AA^{-3}$

$\Delta \rho_{\min }=-0.53$ e $\AA^{-3}$

Absolute structure: Refined as an inversion twin.

Absolute structure parameter: 0.18 (5) 


\section{Special details}

Geometry. All esds (except the esd in the dihedral angle between two 1.s. planes) are estimated using the full covariance matrix. The cell esds are taken into account individually in the estimation of esds in distances, angles and torsion angles; correlations between esds in cell parameters are only used when they are defined by crystal symmetry. An approximate (isotropic) treatment of cell esds is used for estimating esds involving l.s. planes.

Refinement. Refined as a 2-component inversion twin.

Fractional atomic coordinates and isotropic or equivalent isotropic displacement parameters $\left(\hat{A}^{2}\right)$

\begin{tabular}{lllll}
\hline & $x$ & $y$ & $z$ & $U_{\text {iso }} * U_{\text {eq }}$ \\
\hline $\mathrm{Ca}$ & $0.29482(8)$ & $0.9839(2)$ & $0.73974(6)$ & $0.01019(15)$ \\
$\mathrm{Mn}$ & $0.74915(13)$ & $0.7373(2)$ & $0.99906(10)$ & $0.00679(12)$ \\
$\mathrm{Si} 1$ & $0.96440(10)$ & $0.9873(3)$ & $0.84877(8)$ & $0.00607(18)$ \\
$\mathrm{Si} 2$ & $0.89549(12)$ & $1.0016(3)$ & $0.60450(9)$ & $0.0084(2)$ \\
O1 & $0.1260(3)$ & $0.9855(9)$ & $0.9082(2)$ & $0.0088(5)$ \\
O2 & $1.0076(3)$ & $0.9891(10)$ & $0.71434(19)$ & $0.0094(5)$ \\
O3 & $0.8652(5)$ & $0.7699(7)$ & $0.8692(4)$ & $0.0096(9)$ \\
O4 & $0.1302(4)$ & $0.2031(7)$ & $0.1276(3)$ & $0.0070(9)$ \\
O5 & 1.0000 & $1.0402(7)$ & 0.5000 & $0.0169(11)$ \\
O6 & $0.7769(4)$ & $1.1913(6)$ & $0.6146(3)$ & $0.0121(8)$ \\
O7 & $0.8183(4)$ & $0.7611(6)$ & $0.5947(3)$ & $0.0152(9)$ \\
O8 & $0.6317(3)$ & $0.9886(9)$ & $0.9535(2)$ & $0.0096(5)$ \\
O9 & $0.5570(4)$ & $0.9743(11)$ & $0.7213(3)$ & $0.0201(8)$ \\
H1 & $0.792(8)$ & $0.760(12)$ & $0.536(6)$ & $0.040^{*}$ \\
H2 & $0.617(7)$ & $1.029(13)$ & $0.905(5)$ & $0.040^{*}$ \\
H3 & $0.594(7)$ & $1.041(13)$ & $0.679(6)$ & $0.040^{*}$ \\
H4 & $0.586(6)$ & $0.967(18)$ & $0.778(5)$ & $0.040^{*}$ \\
& & & &
\end{tabular}

Atomic displacement parameters $\left(\AA^{2}\right)$

\begin{tabular}{lllllll}
\hline & $U^{11}$ & $U^{22}$ & $U^{33}$ & $U^{12}$ & $U^{13}$ & $U^{23}$ \\
\hline $\mathrm{Ca}$ & $0.0129(4)$ & $0.0101(3)$ & $0.0076(3)$ & $-0.0017(6)$ & $0.0017(3)$ & $-0.0006(6)$ \\
$\mathrm{Mn}$ & $0.0074(2)$ & $0.0068(2)$ & $0.0062(2)$ & $0.00026(19)$ & $0.00176(17)$ & $0.00027(18)$ \\
$\mathrm{Si} 1$ & $0.0063(4)$ & $0.0071(4)$ & $0.0049(4)$ & $-0.0002(8)$ & $0.0009(3)$ & $0.0002(8)$ \\
$\mathrm{Si} 2$ & $0.0101(5)$ & $0.0100(6)$ & $0.0051(4)$ & $-0.0020(7)$ & $0.0008(4)$ & $-0.0003(7)$ \\
O1 & $0.0071(11)$ & $0.0098(10)$ & $0.0094(12)$ & $0.001(2)$ & $-0.0006(9)$ & $-0.002(2)$ \\
O2 & $0.0094(12)$ & $0.0142(11)$ & $0.0045(11)$ & $-0.001(2)$ & $0.0012(9)$ & $0.000(2)$ \\
O3 & $0.007(2)$ & $0.010(2)$ & $0.012(2)$ & $-0.0012(16)$ & $0.0025(18)$ & $-0.0024(17)$ \\
O4 & $0.009(2)$ & $0.007(2)$ & $0.005(2)$ & $-0.0014(16)$ & $0.0018(17)$ & $0.0005(15)$ \\
O5 & $0.019(2)$ & $0.025(3)$ & $0.007(2)$ & 0.000 & $0.0043(17)$ & 0.000 \\
O6 & $0.0127(18)$ & $0.0138(17)$ & $0.0096(17)$ & $0.0018(14)$ & $-0.0006(14)$ & $-0.0011(13)$ \\
O7 & $0.021(2)$ & $0.0131(17)$ & $0.0112(19)$ & $-0.0035(16)$ & $-0.0054(16)$ & $0.0001(15)$ \\
O8 & $0.0113(12)$ & $0.0087(10)$ & $0.0088(12)$ & $0.001(2)$ & $-0.0006(10)$ & $-0.003(2)$ \\
O9 & $0.0172(16)$ & $0.0221(19)$ & $0.0213(17)$ & $-0.006(2)$ & $0.0042(13)$ & $0.001(3)$ \\
& & & & & & \\
\hline
\end{tabular}


Geometric parameters $\left(\AA,{ }^{o}\right)$

\begin{tabular}{|c|c|c|c|}
\hline $\mathrm{Ca}-\mathrm{O}^{\mathrm{i}}$ & $2.348(4)$ & $\mathrm{Mn}-\mathrm{O} 1^{\mathrm{vii}}$ & $2.184(4)$ \\
\hline $\mathrm{Ca}-\mathrm{O} 9$ & $2.386(4)$ & $\mathrm{Mn}-\mathrm{O} 1^{\text {viii }}$ & $2.187(4)$ \\
\hline $\mathrm{Ca}-\mathrm{O} 3^{\mathrm{ii}}$ & $2.422(5)$ & $\mathrm{Si} 1-\mathrm{O} 1^{\mathrm{ix}}$ & $1.608(3)$ \\
\hline $\mathrm{Ca}-\mathrm{O} 4^{\mathrm{iii}}$ & $2.433(4)$ & $\mathrm{Si} 1-\mathrm{O} 4^{\mathrm{x}}$ & $1.611(4)$ \\
\hline $\mathrm{Ca}-\mathrm{O} 7^{\mathrm{ii}}$ & 2.449 (4) & $\mathrm{Si} 1-\mathrm{O} 3$ & $1.635(5)$ \\
\hline $\mathrm{Ca}-\mathrm{O} 1$ & $2.557(2)$ & $\mathrm{Si} 1-\mathrm{O} 2$ & $1.664(2)$ \\
\hline $\mathrm{Ca}-\mathrm{O} 2^{\mathrm{iv}}$ & $2.606(3)$ & $\mathrm{Si} 2-\mathrm{O} 6$ & $1.593(4)$ \\
\hline $\mathrm{Mn}-\mathrm{O} 3$ & $1.906(4)$ & $\mathrm{Si} 2-\mathrm{O} 5$ & $1.6031(13)$ \\
\hline $\mathrm{Mn}-\mathrm{O} 4^{\mathrm{v}}$ & $1.909(4)$ & $\mathrm{Si} 2-\mathrm{O} 2$ & $1.640(3)$ \\
\hline $\mathrm{Mn}-\mathrm{O} 8$ & $1.949(5)$ & $\mathrm{Si} 2-\mathrm{O} 7$ & $1.642(4)$ \\
\hline $\mathrm{Mn}-\mathrm{O} 8^{\mathrm{vi}}$ & $1.951(5)$ & & \\
\hline $\mathrm{O} 3-\mathrm{Mn}-\mathrm{O} 4^{v}$ & $179.1(3)$ & 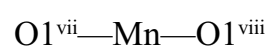 & $179.1(2)$ \\
\hline $\mathrm{O} 3-\mathrm{Mn}-\mathrm{O} 8$ & $89.73(16)$ & $\mathrm{O} 1^{\mathrm{ix}}-\mathrm{Si} 1-\mathrm{O} 4^{\mathrm{x}}$ & $114.1(2)$ \\
\hline $\mathrm{O} 4^{\mathrm{v}}-\mathrm{Mn}-\mathrm{O} 8$ & $89.97(16)$ & $\mathrm{O} 1^{\mathrm{ix}}-\mathrm{Si} 1-\mathrm{O} 3$ & $115.0(3)$ \\
\hline $\mathrm{O} 3-\mathrm{Mn}-\mathrm{O}^{\mathrm{vi}}$ & 90.51 (17) & $\mathrm{O} 4^{\mathrm{x}}-\mathrm{Si} 1-\mathrm{O} 3$ & $110.88(13)$ \\
\hline $\mathrm{O} 4^{\mathrm{v}}-\mathrm{Mn}-\mathrm{O}^{\mathrm{vi}}$ & $89.81(16)$ & $\mathrm{O} 1^{\mathrm{ix}}-\mathrm{Si} 1-\mathrm{O} 2$ & $101.23(13)$ \\
\hline $\mathrm{O} 8-\mathrm{Mn}-\mathrm{O}^{\mathrm{vi}}$ & $179.1(2)$ & $\mathrm{O} 4^{\mathrm{x}}-\mathrm{Si} 1-\mathrm{O} 2$ & $107.6(3)$ \\
\hline $\mathrm{O} 3-\mathrm{Mn}-\mathrm{O} 1^{\mathrm{vii}}$ & $87.33(17)$ & $\mathrm{O} 3-\mathrm{Si} 1-\mathrm{O} 2$ & $107.0(3)$ \\
\hline $\mathrm{O} 4^{\mathrm{v}}-\mathrm{Mn}-\mathrm{O} 1^{\mathrm{vii}}$ & $91.84(15)$ & $\mathrm{O} 6-\mathrm{Si} 2-\mathrm{O} 5$ & $111.1(2)$ \\
\hline $\mathrm{O} 8-\mathrm{Mn}-\mathrm{O}^{\mathrm{vii}}$ & $99.16(17)$ & $\mathrm{O} 6-\mathrm{Si} 2-\mathrm{O} 2$ & $112.1(2)$ \\
\hline $\mathrm{O} 8^{\mathrm{vi}}-\mathrm{Mn}-\mathrm{O} 1^{\mathrm{vii}}$ & $81.73(17)$ & $\mathrm{O} 5-\mathrm{Si} 2-\mathrm{O} 2$ & $105.51(11)$ \\
\hline $\mathrm{O} 3-\mathrm{Mn}-\mathrm{O} 1^{\mathrm{vii}}$ & $92.99(16)$ & $\mathrm{O} 6-\mathrm{Si} 2-\mathrm{O} 7$ & $112.6(2)$ \\
\hline $\mathrm{O} 4^{\mathrm{v}-}-\mathrm{Mn}-\mathrm{O} 1^{\mathrm{viii}}$ & $87.85(16)$ & $\mathrm{O} 5-\mathrm{Si} 2-\mathrm{O} 7$ & $109.7(2)$ \\
\hline $\mathrm{O} 8-\mathrm{Mn}-\mathrm{O} 1^{\mathrm{viii}}$ & $81.70(17)$ & $\mathrm{O} 2-\mathrm{Si} 2-\mathrm{O} 7$ & $105.5(3)$ \\
\hline 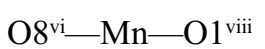 & $97.41(16)$ & & \\
\hline
\end{tabular}

Symmetry codes: (i) $x-1 / 2, y-1 / 2, z$; (ii) $x-1 / 2, y+1 / 2, z$; (iii) $-x+1 / 2, y+1 / 2,-z+1$; (iv) $x-1, y, z$; (v) $x+1 / 2, y+1 / 2, z+1$; (vi) $-x+3 / 2, y-1 / 2,-z+2$; (vii) $x+1 / 2, y-1 / 2, z$; (viii) $-x+1, y,-z+2$; (ix) $x+1, y, z$; (x) $-x+1, y+1,-z+1$.

Hydrogen-bond geometry $\left(\AA,{ }^{\circ}\right)$

\begin{tabular}{|c|c|c|c|c|}
\hline$D-\mathrm{H} \cdots A$ & $D-\mathrm{H}$ & $\mathrm{H} \cdots A$ & $D^{\cdots} A$ & $D-\mathrm{H} \cdots A$ \\
\hline $\mathrm{O} 7-\mathrm{H} 1 \cdots \mathrm{O}^{\mathrm{xi}}$ & $0.73(6)$ & $1.94(6)$ & $2.662(4)$ & $168(8)$ \\
\hline $\mathrm{O} 8-\mathrm{H} 2 \cdots \mathrm{O} 9$ & $0.64(6)$ & $2.28(6)$ & $2.842(4)$ & $149(9)$ \\
\hline $\mathrm{O} 9-\mathrm{H} 3 \cdots \mathrm{O} 6$ & $0.74(8)$ & $2.06(8)$ & $2.737(6)$ & $153(7)$ \\
\hline $\mathrm{O} 9-\mathrm{H} 4 \cdots \mathrm{O} 8$ & $0.72(6)$ & $2.14(6)$ & $2.842(4)$ & $167(9)$ \\
\hline
\end{tabular}

Symmetry code: (xi) $-x+3 / 2, y-1 / 2,-z+1$. 